\title{
Effect of Loading Rate and Moisture Content on the Fracture Resistance of Beechwood (Gmelina arborea) Seed
}

\author{
NYORERE, O; *UGURU, H \\ Department of Agricultural and Bio-Environmental Engineering Technology, Delta State Polytechnic, Ozoro, Delta State, Nigeria \\ *Corresponding Author Email: erobo2011@gmail.com
}

\begin{abstract}
Mechanical properties of agricultural materials are necessary for the proper design and development of their planting, harvesting, handling and processing machineries. In this research, fracture resistance of whole gmelina seed was evaluated in terms of its rupture force, rupture energy and deformation at rupture under four moisture content levels and three loading rates. The quasi-static compressive tests were conducted at 20, 25, 30 and 35 percent moisture levels (wb); and 5, 10 and $15 \mathrm{~mm} / \mathrm{min}$ loading rates. Based on the results obtained, moisture content and loading rate had significant $(\mathrm{P} \leq 0.05)$ effect on all the three parameters investigated. The force required for initiating seed rupture decreased with increase in moisture content and loading rate. The highest rupture energy was $0.268 \mathrm{Nm}$ at $35 \%$ moisture content under $5 \mathrm{~mm} / \mathrm{min}$ loading rate, and the lowest was $0.116 \mathrm{Nm}$ at $20 \%$ moisture content under $15 \mathrm{~mm} / \mathrm{min}$ loading rate. In addition, the deformation capability of the seed decreased from $1.017 \mathrm{~mm}$ at $35 \%$ moisture content (wb), under $5 \mathrm{~mm} / \mathrm{min}$ loading rate, to $0.458 \mathrm{~mm}$ at $20 \%$ moisture content (wb) under $15 \mathrm{~mm} / \mathrm{min}$ loading rate. The results obtained from this research would be useful in the design and development of machines used in gmelina seed processing operations.
\end{abstract}

\section{DOI: https://dx.doi.org/10.4314/jasem.v22i10.14}

Copyright: Copyright (C) 2018 Nyorere and Uguru. This is an open access article distributed under the Creative Commons Attribution License (CCL), which permits unrestricted use, distribution, and reproduction in any medium, provided the original work is properly cited.

Dates: Received: 10 September 2018; Revised: 12 October 2018; Accepted: 29 October 2018

Keywords: Gmelina seed, Fracture resistance, Moisture content, loading rate

Gmelina arborea (Gmelina arboreal Roxb) is a fastgrowing tree, which grows on different localities and prefers moist fertile valleys, they attain moderate to large height up to $40 \mathrm{~m}$ and $140 \mathrm{~cm}$ in diameter (Tewari, 1995). It is occurring naturally throughout greater part of India at altitudes up to $1500 \mathrm{~m}$. It also occurs naturally in Myanmar, Thailand, Laos, Cambodia, Vietnam, and in southern provinces of China, and has been planted extensively in Sierra Leone, Nigeria and Malaysia (Adegbehin and Nwaigbo, 1988). The fruits, leaves and seeds extract of gmelina have been reported by many authours from various locations to contain nutrients, mineral constituents and phytochemicals like alkaloids, steroids, carbohydrates, anthraquinone, glycosides, triterpenoids, saponinns gums, mucilages, tannins, phenolic compounds and flavonoids and proteins (Adegbehin and Nwaigbo,1988 and Nayak et al., 2012).

Some impact of moisture content and loading rates on the mechanical properties of grains and seeds have been investigated by previous researchers. The shelling resistance of white speckled red kidney bean grain decreased with increased in moisture content of the grain (Işik and Ünal, 2007). Saiedirad et al. (2008) studied effects of moisture content, seed size, loading rate and seed orientation on force and energy required for fracturing cumin seed under quasi static loading. Their results showed that the force required for initiating seed rupture decreased from 15.7 to $11.96 \mathrm{~N}$ and 58.2 to $28.8 \mathrm{~N}$, and the energy absorbed at seed rupture increased from 1.8 to $8.6 \mathrm{~mJ}$ and 7.6 to 14.6 $\mathrm{mJ}$, with increase in moisture content from $5.7 \%$ to $15 \%$ d.b., for vertical and horizontal orientations, respectively. In addition, Babic et al., (2013), worked on six corn hybrids, and observed that the deformation - head displacement at the ultimate strength point of the kernels increased, as the moisture content of the kernels increased for all compression tests. Mamman and Umar (2005) studied the effects of moisture content and loading orientation on the mechanical properties of balanites nuts. They reported that the six mechanical properties investigated (modulus of elasticity, bioyield point, bioyield stress, compressive strength, rupture strength and modulus of stiffness), decreased with increase in moisture content.

Study of mechanical behaviour of gmelina seed is important, especially at dehulling and cracking stages of the seed. Only few researches have been conducted on the physical and mechanical properties of gmelina fruit and seed. Oghenerukevwe and Uguru (2018) reported that gmelina fruit's size and orientation affected its mechanical properties. In their report, lowest values of mechanical parameters were obtained 
at smallest fruit size. However, there is no cited literature on the effect of seed moisture content and loading rate on the fracture resistance of gmelina seed. Therefore, the objective of this study was to investigate the fracture resistance of gmelina seed at different moisture contents $(20,25,30$, and $35 \% \mathrm{wb})$ and loading rates $(5,10$ and $15 \mathrm{~mm} / \mathrm{min})$. This is to evaluate the impact of moisture content and loading rate on the fracture resistance of gmelina seed, which is essential for the design and development of gmelina processing machines.

\section{MATERIALS AND METHODS}

Samples collection: The gmelina fruits were obtained from Delta State Polytechnic, Ozoro, Delta State, Nigeria. The fruits were soaked in water for ten days to facilitate the separation the seeds from the fruits pulp. The recovered seeds were sun-dried for ten days, to attain uniform moisture content. After the sun drying, the seeds were cleaned manually, where foreign matters, broken and immature seeds were removed.

Moisture content determination and reconditioning of the seeds: The mean initial moisture content of the seed was determined by the standard hot air oven method (ASAE, 1999). The rewetting formula used was Equation 1. The conditioned samples were sealed in low density polyethylene bags of $90 \mu \mathrm{m}$ thickness, kept in a refrigerator at $4^{\circ} \mathrm{C}$ for one week for uniform moisture distribution throughout the sample. Before starting the experiment, a required quantity of the sample was taken out from the refrigerator and allowed to equilibrate with room temperature for two hours (Singh and Goswami, 1996).

$\Delta M_{w}=W_{t}\left(\frac{M_{f}-M_{i}}{100-M_{f}}\right)$

Where $\mathrm{M}_{\mathrm{i}}=$ initial moisture content (\% wet basis), $\mathrm{M}_{\mathrm{f}}$ $=$ final moisture content $(\%$ wet basis $), \mathrm{W}_{\mathrm{t}}=$ total weight of sample, $(\mathrm{g})$

Mechanical properties determination: The Quasistatic compression tests of the gmelina seeds were performed using a Universal Testing Machine (Testometric model) equipped with a $50 \mathrm{~N}$ compression load cell and integrator, with measurement accuracy of 0.001 , at the Material Testing Laboratory of the National Center for Agricultural Mechanization (NCAM), Ilorin, Kwara state, Nigeria. Individual gmelina seed was loaded between two parallel plates, and compressed at the crosshead speed of 5,10 or $15 \mathrm{~mm} / \mathrm{min}$ as the case may be, until rupture occurred. As the compression progresses, the mechanical parameters (rupture force, rupture energy and deformation at rupture) were generated automatically by the machine. Also, a loaddeformation curve was plotted automatically in relation to the response of each seed to compression. The mechanical properties were determined at moisture content levels of 20, 25, 30, and $35 \% \mathrm{wb}$, and three loading rates of 5,10 , and $15 \mathrm{~mm} / \mathrm{min}$. Twenty seeds were tested at each moisture level, and loading rate, then the average recorded.

Due to changing surface area contact between gmelina seed and the compressive plate during compression, the rupture stress is difficult to determine; therefore, rupture energy seems to be a better parameter of the seed hardness. Since gmelina seed is a biological material, it has complex biomechanical systems of very complex behaviour and cannot be characterized by simple constants (Lysiak, 2007 and Mohsenin, 1986). Therefore, it is necessary to introduce some concepts such as bio-yield and rupture points. The bioyield point indicates the initial cell rupture in the whole seed and is used as a criterion for maximum allowable load that the gmelina seed can sustains without showing any visible damage (Mohsenin el al., 1965). The rupture point dictates failure over a significant volume of material causing fracture planes or cracks in the macrostructure of the gmelina seed. The rupture energy (Toughness) is the work required to initiate rupture of the gmelina seed, which is the area under the force-deformation curve up to the rupture point (Mohsenin, 1986). The deformation (strain) of the seed is the change in the original dimension of the seed during compression.

Statistical analysis: The results of physical properties were subjected to analysis of variance (ANOVA) to evaluate a statistical significance of observed differences among treatment means at $95 \%$ confidence level using SPSS 20.0 software (IBM Corporation, USA). The $F$ test was used to determine significant effects of each treatment, and Duncan's multiple ranges test was used to separate means at the $5 \%$ probability level.

\section{RESULTS AND DISCUSSION}

The analysis of variance (ANOVA) result (Table 1) shows moisture content and loading rate had significant $(\mathrm{P}<0.05)$ effect on rupture force, rupture energy and deformation at rupture point. According to Table 1, the interaction effects of moisture content and loading rate were not significant on rupture force and rupture energy, but was significant $(\mathrm{P}<0.05)$ on the deformation at rupture of the gmelina seed. 
Table 1: Analysis of the variance of parameters considered on rupture force, rupture energy and deformation at rupture of gmelina seed

\begin{tabular}{|c|c|c|c|c|c|c|c|}
\hline \multirow[t]{2}{*}{ Source of variation } & \multirow[t]{2}{*}{ df } & \multicolumn{2}{|c|}{ Rupture force } & \multicolumn{2}{|c|}{ Rupture energy } & \multicolumn{2}{|c|}{ Deformation at rupture } \\
\hline & & $\mathrm{F}$ & sig & $\mathrm{F}^{1}$ & sig & $\mathrm{F}$ & Sig \\
\hline $\mathrm{L}$ & 2 & 27.78 & $5.02 \mathrm{E}-08 *$ & 95.45 & $4.05 \mathrm{E}-15^{*}$ & 88.23 & $1.32 \mathrm{E}-14^{*}$ \\
\hline M & 3 & 34.48 & $1.10 \mathrm{E}-10 *$ & 40.49 & $1.25 \mathrm{E}-11 *$ & 137.06 & $9.47 \mathrm{E}-20 *$ \\
\hline $\mathrm{L} \times \mathrm{M}$ & 6 & 0.88 & $0.51788^{\mathrm{ns}}$ & 1.36 & $0.25671^{\mathrm{ns}}$ & 12.48 & $1.47 \mathrm{E}-07 *$ \\
\hline
\end{tabular}

Rupture force: The research results showed that the force needed to rupture (crack) gmelina seed was a function of moisture content and loading rate. As shown in Figure 1, the force required for initiating gmelina seed rupture decreased with increase in moisture content. In addition, the results showed that the rupture force decreased as loading rate increased from 5 to $15 \mathrm{~mm} / \mathrm{min}$, at all the moisture content levels. According to Duncan's multiple range tests, the rupture force of the gmelina seed at $20 \%$ moisture content was significantly higher $(\mathrm{p} \leq 0.05)$ than $25 \%$, $30 \%$ and $35 \%$ moisture content. The Duncan test also showed that there were significant differences ( $p$ $\leq 0.05$ ) between the three loading speeds.

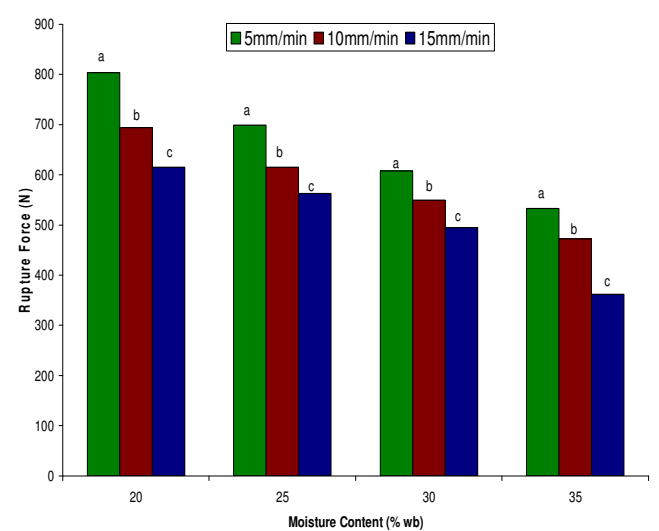

Fig 1: Effect of moisture content and loading rate on rupture force of gmelina seed. The columns with the same latter are not significantly different $(\mathrm{P}<0.05)$ according to Duncan's multiple ranges test

For all the moisture content evaluated, the highest rupture force $(803.6 \mathrm{~N})$ was obtained at $20 \%$ moisture content and loading rate of $5 \mathrm{~mm} / \mathrm{min}$. While the lowest rupture force $(361.7 \mathrm{~N})$ corresponded to $35 \%$ moisture content at $15 \mathrm{~mm} / \mathrm{min}$ loading rate (Figure 1). This could be attributed to weaken structure of the seed cells, induced by higher moisture content; thereby lowering its resistance to higher compressive force. Similar results of effect of loading rate on rupture force and energy were reported by Saiedirad et al. (2008) for cumin seed. Also, Altuntaş and Yildiz (2007) noted in their research that the rupture force of faba bean grains ranged from 314.17 to $185.10 \mathrm{~N}$, as the moisture content increased from $9.89 \%$ to $25.08 \%$, wb. The increasing trend of rupture force with an increase in moisture content was also documented by Baumler $e t$ al. (2006), who observed that during the quasi-static compressive loading of safflower seed, the force required for hull rupture decreases as the moisture content increased.

Rupture Energy (Toughness): The results showed that the energy needed to rupture the gmelina seed was a function of both moisture content and loading rate (Figure 2). The rupture energy of the gmelina seed continued to decline as the compressive loading rate increased from $5 \mathrm{~mm} / \mathrm{min}$ to $15 \mathrm{~mm} / \mathrm{min}$. In addition, smaller energy was required to initiate gmelina seed rupture at higher moisture content (Figure 2).

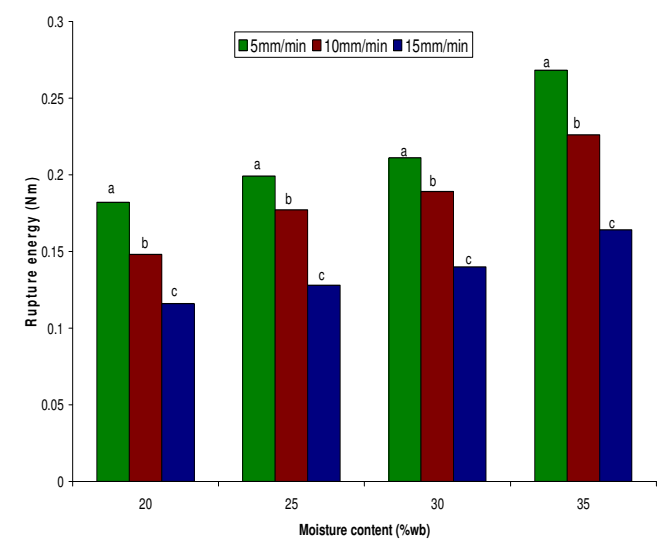

Fig 2: Effect of moisture content and loading rate on rupture energy of gmelina seed. The columns with the same latter are not significantly different $(\mathrm{P}<0.05)$ according to Duncan's multiple ranges test

This was because at higher moisture content, the seed became softer and required lesser energy to crack (Saiedirad et al., 2008; Khodabakhshian et al., 2010). According to Duncan's multiple range test, the values of rupture energy had significant differences $(\mathrm{p}<0.05)$ from each other for three loading speeds and moisture contents. Khodabakhshian et al. (2010) investigated mechanical properties of Iranian sunflower seed under quasi static loading, and observed that rupture force for both seed and kernel decreased with increasing moisture content from 3 to $14 \%$. Similar result was reported by Kermani et al. (2008), who investigated energy absorbed in brown rice rupture under quasistatic compressive loading and reported that with an 
increased in grain moisture content, the energy absorbed by the grains increases too.

Deformation at rupture: The results of the effect of moisture content and loading rate on the deformation of the gmelina seed are presented in Figure 3. The results revealed that the deformation at seed rupture point increased with increase in moisture content, but decreased with increase in the seed loading rate. These observations depicted that, at higher moisture content and lower loading speed, gmelina seed will experience more deformation, making mechanical damage inevitable.

This observation is consistent with the finding of Burubai et al., (2008) who observed a deformation of $0.63 \mathrm{~mm}$ at 8.0 percent moisture and $1.538 \mathrm{~mm}$ at 28.7 percent moisture all in the axial loading position on Africa nutmeg. Zoerb (1967) reported that most agricultural materials are elastic during the first portion of a load-deformation curve, but the increased in loading rate increases their viscoelastic properties. Thus, once the elastic region is extended, properties are time-dependent and the effect of loading rate becomes more noticeable. In addition, Baritelle and Hyde (2000) determined strain rate and size effects on pear tissue failure. They observed that as the strain rate increased, the failure stress also increased while failure strain remained nearly the same. Thus, toughness and stiffness of pear both increased with increasing strain rate.

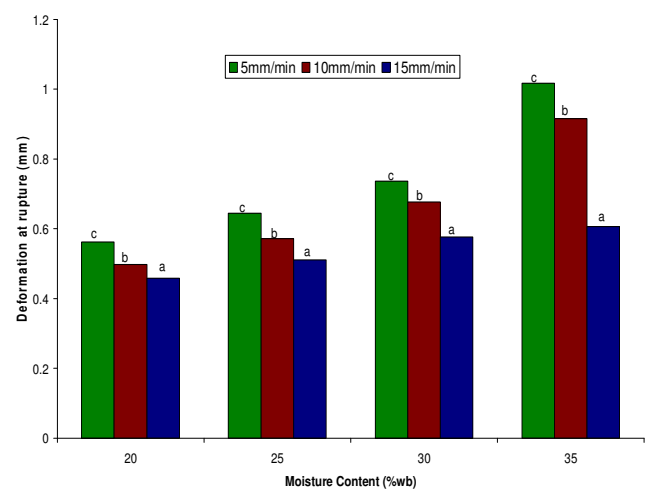

Fig 3: Effect of moisture content and loading rate on deformation at rupture of gmelina seed. The columns with the same latter are not significantly different $(\mathrm{P}<0.05)$ according to Duncan's multiple ranges test

Engineering implications of results: Knowledge of this compressive properties as a function of moisture content and loading speed is vital in the processing of gmelina seeds. For product quality and energy conservation, it is recommended that seeds should be cracked at lower moisture content and higher compressive loading speed. This is because, trying to crack the seed at higher moisture content, the seed will experience larger deformation, resulting in breakages and poor product quality.

Conclusions: This present study was carried out to investigate the impact of loading rate and moisture content on the fracture resistance of gmelina seed. The results showed that the fracture resistance of the seeds was both function of the moisture content of the seed and the loading rate. The rupture force, rupture energy and deformation of the seed decreased with an increase in the loading rate. While the rupture force of the seed increased with decreased in moisture content of the seed; the rupture energy and deformation increased with increase in moisture content of the seed. The knowledge of fracture resistance of gmelina seed is essential for the design and development of its processing machines.

\section{REFERENCES}

Adegbehin, J; Nwaigbo, L (1988). Gmelina arboreal in Nigeria. Common. For. Rev. 67(2):159-166.

Altuntaş E; Yildiz, M (2007). Effect of moisture content on some physical and mechanical properties of faba bean (Vicia faba L.) grains. $J$ Food Eng 78: 174-183.

ASAE (1999). ASAE Standards S352.2. Moisture measurement - unground grain and seeds. ASAE, St. Joseph, MI, USA

Babic, LJ; Radojcin, M; Pavkov, I; Babic, M; Turan, J; Zoranovic, M; Stanisic, S (2013). Physical properties and compression loading behavior of corn seed. Int. Agrophys. 27: 119-126

Baumler. E; Cuniberti, A; Nolasco, SM; Riccobene, IC (2006). Moisture dependent physical and compression properties of safflower seed. J. Food Eng. 72: 134-140.

Baritelle, A; Hyde, GM (2000). Strain rate and size effects on pear tissue failure. Transactions of the ASAE. 43 (1): 95-98.

Burubai, W; Akor, AJ; Igoni, AH; Puyate, YT (2008). Fracture resistance of African nutmeg (Monodora myristica) to compressive loading. Am-Euras. J. Sci. Res. 3: 15-18.,

Işik, E; Ünal, H (2007) Moisture-dependent physical properties of white speckled red kidney bean grains. J Food Eng 82: 209-216. 
Kermani, AM; Tavakoli, HT; Minaei, S (2008). Investigation and determination of moisture content and temperature effects on the mechanical properties of brown rice. Iranian Journal of Agricultural Engineering Research. 9 (3): 53-74.

Khodabakhshian, R; Emadi, B; Fard, MHA; Saiedirad, MH (2010). Mechanical properties of sunflower seed and its kernel, azargol variety as a case study, under compressive loading. J. Agric. Sci. Technol., 4 (2):34-40.

Lysiak, G (2007). Fracture toughness of pea: Weibull Analysis. J Food Eng, 83: 436-443

Mamman, E; Umar, B (2005). Effects of moisture content and loading orientation on the mechanical properties of balanites aegyptiaca nuts. J. Sci. Res. 7 (2): 20-25.

Mohsein, NN; Morrow, CT; Tukey, LD (1965). The "Yield -Point" non-destructive technique for pending firmness of golden delicious apples. Proc Am, Soc Hort. Sci. 86(1): 70 - 80

Mohsenin, NN (1986). Physical Properties of Plant and Animal Materials. Gordon and Breach Science Publishers, New York pp 8-11, Books Ltd London 487 - 492.
Nayak, BS.; Jena, PK; Dinda, SC; Ellaiah, P (2012). Phytochemical investigation and in vitro evaluation of anthelmintic activity of Gmelina arborea roxb. fruit extracts. Asian Journal of Chemistry. 24(8): 3445-48.

Oghenerukevwe, P; Uguru, H (2018). Effect of fruit size and orientation on mechanical properties of Gmelina Fruit (Gmelina arborea) under quasistatic loading. International Journal of Engineering and Technical Research. 8 (4): 47 51

Saiedirad, MH; Tabatabaeefar, A; Borghei, M (2008). Effect of moisture content, seed size, loading rate and seed orientation on force and energy required for fracturing cumin seed under quasi-static loading. J. Food Eng. 86: 565-572.

Singh, KK; Goswami, TK (1996). Physical properties of cumin Seed. J. Agric. Eng. Res. 64: 93-98

Tewari, DN (1995). A Monograph on Gamari (Gmelina arboreal Roxb). International Book Distributors.

Zoerb, GC (1967). Instrumentation and measurement techniques for determining physical properties of farm products. Transactions of the ASAE. 10: 100-113. 